\title{
The Commitment of the Employee to the Supervisor and the Organization: The Role of Employee Competency and Downward Influence Tactics
}

\section{Tuty Lindawati}

Management Department, Faculty of Business, Widya Mandala Catholic University, Surabaya, Indonesia

\section{Fenika Wulani}

Management Department, Faculty of Business, Widya Mandala Catholic University, Surabaya, Indonesia

\section{Abstract}

Employee's commitment is an important work attitude for an organization. Supervisors can play a role in increasing it by conducting downward influence tactics. This study examines the relationship between employee competency and downward influence tactics (consultation, ingratiation, and exchange tactics), the relationship between these tactics and employee's commitment to the supervisor and the organization, and the mediating effect of these tactics on the relationship between employee competency and employee's commitment. Data were collected from 203 non-managerial employees who work in various industries in Surabaya, Indonesia. We analyzed the collected data by using PLS-SEM. This study found that employee competency has a significant positive relationship with downward influence tactics (consultation, ingratiation, and exchange tactics). In addition, consultation and ingratiation tactics have a significant relationship with one's commitment to one's supervisor, but only consultation tactic has a significant relationship with organizational commitment. The consultation tactic has a mediation effect on the relationship between employee competency and organizational commitment, and the commitment to the supervisor.

Keywords: Employee Competency, Downward Influence Tactics, Commitment to Supervisor, Organizational Commitment. 


\section{Introduction}

One interesting topic that researchers have investigated is employee commitment (Sungu et al., 2019). Commitment is defined as a mind-set that binds an individual to a course of action relevant to a particular target (Vandenberghe et al., 2004). Commitment is one of the important elements for attaining high performance since people who are committed will act, be enthusiastic, and show effort and persistence to complete their tasks successfully (Falbe \& Yukl, 1992). Employee commitment has several foci, such as the organization and the supervisor (Sungu et al., 2019). A foci commitment that is considered important may affect their behavior (Vandenberghe et al., 2004), such as organizational commitment and commitment to the supervisor that affects turnover intent (e.g., Hung et al., 2018; Flint at al., 2013; Meyer et al., 2015). Given the high business competition, organizations need to increase employee commitment, especially those who have high competencies.

The previous studies indicated that highly competent employees would have high commitment (e.g., Naim \& Lenka, 2017). However, the mechanism of how competent employees could have high commitment has not been much investigated in existing studies. Several studies have indicated that leaders have a role to increase employee commitment (Chaturvedi et al., 2019; Shin \& Hyun, 2019). The current study offers downward influence tactics as a mediator for the relationship between employee competency and commitment.

Some studies showed that employee commitment could be developed through downward influence tactics (e.g. Chaturvedi et al., 2019; Shin \& Hyun, 2019), which is a supervisor's action to change the attitude, belief, or behavior of another individual who is his/her target (Knippenberg et al., 1999; Shin \& Hyun, 2019). Supervisors may engage in downward influence tactics by doing or promising something or providing the things that the subordinates enjoy before asking them to do something. In line with the social exchange theory that individual employees will repay good treatment with good behavior (Organ, 1974), supervisors need to use downward influence tactics targeted to their subordinates in order to make their subordinates happy and accomplish what they want (Lee \& Salleh, 2009). As a result, subordinates respond to these tactics by being committed and willing to comply with their supervisors' wishes (Tepper et al., 1998) as well as those of the organization (Chong et al., 2013).

According to Chong et al. (2013), several influence tactics are available to supervisors, which could be effective for increasing employees' commitment. Some studies showed that consultation, ingratiation, and exchange tactics are the kinds of tactics used by supervisors on their subordinates (Lee et al., 2017; Soetjipto, 2002) and related to employee commitment (Lee et al., 2017). Since the meaning of exchange relationship depends on the perception of the individuals in the relationship (Chong et al., 2013), and this perception may have an impact on the individuals' behavior (Cogliser et al., 2009), this study asks individuals to perceive tactics used by their supervisor. The use of the subordinates' perception is in line with this study's purpose, i.e., to investigate the impact of downward influence tactics on employee commitment.

This current research has two purposes. First, it examines the effect of employee competency on downward influence tactics, and the effect of downward influence 
tactics on employee commitment. We develop these relationships based on social exchange theory. This study addresses the issues regarding supervisors' influence tactics toward their competent employees and whether subordinates prefer to commit to their supervisors rather than the organization. Lee and Salleh (2009) and Lee and Low (2012) researched the relationship between employee competency and influence tactics. Nevertheless, they tended to focus on the mediating role of those variables. Also, there is a dearth of studies that have investigated this relationship. This present study investigates three types of tactics: consultation, ingratiation, and exchange tactics, based on individual subordinates' perceptions.

Furthermore, the individuals' perception of the social exchange agent will influence the one they will reciprocate (Flint et al., 2013). Previous studies indicated that downward influence tactics are correlated to employees' commitment (e.g., Asawo \& George, 2018; Chaturvedi et al., 2019). However, the previous studies tended to emphasize the impact of downward influence tactics on subordinates' commitment to the organization and the job. Meanwhile, employees may commit to different foci, depending on their perception of who does the social exchange (Hansen et al., 2013; Yousaf et al., 2015). Compared to organizations' treatments, supervisor' treatments more result in commitment to the supervisor (Cropanzano \& Mitchell, 2005). Moreover, Hansen et al. (2013) found that employees' perception of social exchanges carried out by their supervisors correlates more strongly with their commitment to supervisors than the one of social exchanges conducted by top management leaders (e.g., top manager). They found that social exchanges by top management are more correlated to organizational commitment. It is possible that subordinates may repay the supervisors' favorable treatment with commitment directed to them. Commitment to the supervisor can make individuals stay in the organization because they would feel bad for their supervisor if they leave (Meyer et al., 2015). It may benefit the supervisor but be detrimental to the organization (Sungu et al., 2019). However, there are very few studies, if any, which identify the impact of downward influence tactics on subordinates' commitment directed to their supervisors.

Second, this present study provides the mechanism of how employee competency influences employees' commitment considering downward influence tactics as the mediating role. Kim and Gausdal (2020) suggested that competent employees may need certain influence tactics. In addition, influence tactics may drive employees' commitment (Chaturvedi et al., 2019), and previous studies showed that downward influence tactics have a mediator role in increasing work outcomes (e.g., Chaturvedi et al., 2019; Lee \& Low, 2012). However, there is a lack of studies investigating this mechanism. Thus, we examine the mediating effect of downward influence tactics on the relationship between employee competency and employee commitment.

\section{Literature Review}

\section{Social Exchange Theory and Cognitive Evaluation Theory}

Social exchange theory (SET) explains the exchange relationship between individuals at work, such as superiors and subordinates (Ferris et al., 2009). Referring to SET, individuals may benefit from their exchange relationships with other parties with their power (e.g., competence, rewards), and one party's behavior can be determined based 
on the other party's conditions (Nunkoo, 2016). In this reciprocal exchange, if one party provides something useful, the other party needs to respond in a pleasant manner (Cropanzano \& Mitchell, 2005). In doing so, SET can be used to explain the basics of supervisors' behavior to subordinates, such as employee competency levels (Podsakoff, 1982). This principle is in line with leadership theories such as Hersey and Blanchard's situational leadership, where supervisors need to adapt their leadership behavior to their subordinates' situation, such as subordinates' skill (Yukl, 2002). Downward influence tactics as a supervisor's treatment to subordinates can be perceived as a positive impression because they may form the subordinates' perception that the leader recognizes and appreciates their abilities (Lian \& Tui, 2012). Thus, it can be argued that in response to subordinates' abilities, supervisors may choose appropriate influence tactics (such as consultation, ingratiation, and exchange) to be considered pleasurable reciprocity by employees. As a result, the more competent employees are, the more they perceive that they receive positive reciprocate from their supervisors. Moreover, SET explains subordinates' attitudes and behavior for the supervisors' actions (Cropanzano \& Mitchell, 2005). If supervisors give social presents to their subordinates (such as help, praise, and privileges), subordinates will feel obliged to reciprocate (Organ, 1974). In addition, supervisors' treatment can be perceived by subordinates as organizational treatment because they are agents of the organization (Khattak et al., 2019). Therefore, referring to this theory, their treatment will determine positive job outcomes, including employee commitments (Paltu \& Brouwers, 2020), both toward them and organizations.

Cognitive evaluation theory (CET) explains that individuals can be motivated by external factors (Deci \& Ryan, 2000), such as supervisors' behaviors. According to this theory, supervisors' treatment of employees will be a stimulus that will be evaluated and responded to by them, for example, by being committed to the organization (Han et al., 2019). Furthermore, based on CET, external stimulus factors in the form of appreciation and recognition of individual abilities will increase their willingness to commit (Chae et al., 2017). Therefore, competent individuals will give their commitment if their abilities are valued and recognized by their supervisors. Supervisors can show their recognition and appreciation to competent subordinates by doing influence tactics. Since individuals' response depends on their supervisors' stimulus, supervisors need to choose an effective stimulus. In addition, competent subordinates may require certain tactics from their supervisors (Kim \& Gausdal, 2020). In sum, referring to the two theories, the supervisors' treatment could determine whether subordinates want to commit to the organization and the supervisor.

\section{The Relationship between Employee Competency and Downward Influence Tactics}

Draganidis and Mentzas (2006:53) define competence as "a combination of tacit and explicit knowledge, behavior, and skills that give someone the potential for effectiveness in task performance." According to Miserandino (1996), perception of competence is individuals' confidence in their abilities. In various studies, competence is defined as a behavioral character that significantly differentiates a subordinate from other subordinates (Lee \& Low, 2012). In addition, Lee and Low (2012) note that perceived competence is not the actual competence but feelings of 
subordinates about the extent of their competence in doing the work and solving problems. In sum, employee competency is knowledge, abilities, and skills possessed by individuals that make them confident to complete their tasks.

Yukl and Falbe (1990) suggest that managers' effectiveness can be measured by their success in influencing others, including their subordinates. Influence is defined as a means used by individuals to change others' attitudes and/or behavior to achieve their goals (Bunner et al., 2019). Fu and Yukl (2000) explain that influence tactics may come in the form of upward influence, downward influence, and lateral influence. Behavior affecting others is called downward influence tactics when supervisors use tactics that target their subordinates' hierarchical status (Shin \& Hyun, 2019). Influence tactics have several goals: benefits for job completion and personal agents, and nurturing friendships ( $\mathrm{Fu} \& \mathrm{Yukl}, 2000$ ). In addition, this influence tactic may be used by managers to communicate requests and assignments to their subordinates (Soetjipto, 2002).

Yukl and Falbe (1990) provide forms of influence tactics that managers may use to influence others. According to Kipnis and Schmidt (1985), influence tactics have three categories: rational, soft, and hard. Rational tactics are used to influence the target's cognition by providing logical arguments, soft tactics are used to influence the psychological aspects of the target, and hard tactics are used to influence targets with threats and manipulation (Falbe \& Yukl, 1992; Shin \& Hyun, 2019). Rational tactics include exchange and rational tactics persuasion, soft tactics include ingratiation, consultation, personal appeals, and inspirational appeals, and hard tactics include coalition, legitimating, and pressure tactics (Falbe \& Yukl, 1992).

Kipnis et al. (1980) found that managers tend to use different tactics to achieve different goals depending on their target. The important targets of influence for managers are their subordinates, because the effectiveness of managers is shown by how they influence their subordinates to do what they are asked for (Yukl \& Michel, 2007). The choice of tactics that must be used may depend on the competence level (Kim \& Gausdal, 2020). The current study considers three types of tactics, namely consultation, ingratiation, and exchange tactics. Yukl and Falbe (1990) explain the definitions of the three tactics as follows. Individuals use consultation tactics to invite targets to participate in strategic planning, support, and assistance. Ingratiation is done by individuals using praise, excessive flattery, friendly behavior, or help for targets and makes them happy before perpetrators ask for their support. Whereas individuals carry out exchange tactics by giving explicit and implicit promises, they will give rewards and benefits if their subordinates meet their demands.

Previous studies have investigated the effectiveness of these influence tactics. Based on the interviews with the participants in her study, Chong (2014) found that managers often use ingratiation and exchange tactics. Lee and Salleh (2009) argue that supervisors may use downward influence tactics because of subordinates' competence level. In regard to high subordinate competence, supervisors may use downward influence tactics such as consultation (Lee \& Salleh, 2009; Deniz et al., 2018). Since consultation and exchange tactics allow supervisors and subordinates to communicate and share information (Kim \& Gausdal, 2020), this tactic may be suitable for competent subordinates. Moreover, in their study in Malaysia, Lee and Low (2012) found that subordinate competence positively correlates with downward 
influence tactics in the form of consultation and ingratiation tactics. It can be argued therefore that a consultation tactic is carried out by supervisors as a form of recognition of their subordinates' abilities, the ingratiation tactic as a way of showing attention to their subordinates, and an exchange tactic as a way for their employees to make social investments. Thus, the higher the competency of employees, the more supervisors use influence tactics in the form of consultation, ingratiation, and exchange tactics. Hence, we propose that:

H1a Employee competency is positively related to consultation tactics.

H1b Employee competency is positively related to ingratiation tactics.

H1c Employee competency is positively related to exchange tactics.

\section{The Relationship between Downward Influence Tactics and Employee Commitment}

Meyer and Herscovitch (2001:301) define commitment as "a force that binds an individual to a course of action of relevance to one or more targets." In addition, commitment is "a stabilizing force that gives direction to behavior" (Meyer \& Herscovitch, 2001:301). Subordinates will commit to targets that provide support and assistance and trust them (Emuwa, 2013). Flint et al. (2013) suggest that commitment may have multiple targets, such as commitment to the organization and to the supervisor. Organizational commitment has been defined as the strength of individual identification with, and involvement in, a particular organization and wish to maintain his/her membership in the organization in order to achieve its goals (Mowday el al., 1979). On the other hand, commitment to one's supervisor or supervisory commitment is "contingent upon perceptions of an exchange relationship between individuals and their supervisors" (Flint et al., 2013:558). Based on the social exchange theory, individuals will repay other parties' treatment for them (Organ, 1974), and to whom individuals will give a response is dependent on their perceptions of social exchange actors (Flint et al., 2013; Hansen et al., 2013), such as their supervisors (Landry \& Vandenberghe, 2009). Supervisors' behaviors may encourage employee commitment (Sungu et al., 2019), for example, by using downward influence tactics (Chaturvedi et al., 2019; Shin \& Hyun, 2019).

Downward influence tactics such as exchange, ingratiation, and consultation may shape the subordinates' perceptions of their supervisors' goodness. Rational tactics such as exchange tactics; and soft tactics such as ingratiation and consultation tactics are very effective in increasing employee commitment (Kim \& Gausdal, 2020). Empirically, previous studies found that downward influence tactics are correlated with organizational commitment (e.g., Chaturvedi et al., 2019; Chong et al., 2013). In the context of the exchange tactics, supervisors will provide valuable resources if subordinates can meet their supervisors' requests. A meta-analysis study by Lee et al. (2017) found that the consultation tactic is a strategy that has a high correlation with work outcomes. Chong et al. (2013) found that tactics such as consultation were more effective in increasing organizational commitment in Hong Kong, Taiwan, and China. Chong (2014), who used a sample in Hong Kong and Japan, found that ingratiation and consultation tactics have a high relationship with organizational commitment. These findings are in line with Lam et al., (2015), who argued that some influence 
tactics could be more effective in building certain commitments. In sum, consultation tactics allow employees to feel their supervisor recognized their abilities, ingratiation tactics make them feel cared about by their supervisors, and exchange tactics provide rewards as a stimulus to them. Thus, downward influence tactics may impact organizational commitment and commitment to the supervisor. Therefore, we propose that:

$\mathrm{H} 2 \mathrm{a}$ Consultation tactics is positively related to organizational commitment.

$\mathrm{H} 2 \mathrm{~b}$ Ingratiation tactics is positively related to organizational commitment.

$\mathrm{H} 2 \mathrm{c}$ Exchange tactics is positively related to organizational commitment.

H3a Consultation tactics is positively related to commitment to the supervisor.

$\mathrm{H} 3 \mathrm{~b}$ Ingratiation tactics is positively related to commitment to the supervisor.

$\mathrm{H} 3 \mathrm{c}$ Exchange tactics is positively related to commitment to the supervisor.

\section{The Mediating Role of Downward Influence Tactics}

Supervisors' treatments, such as rewarding and developing opportunities, are important for competent employees (Mutonyi et al., 2020). Based on CET, individuals who receive certain treatment stimuli from their supervisor will encourage them to commit. Moreover, referring to SET, supervisors may choose influence tactics that their subordinates perceive as positive treatment of their competencies. In addition, individuals who experience favorable treatments, such as recognition, appreciation, and attention, from their supervisor will positively reciprocate in the form of commitment toward the organization and their supervisor. Some previous studies found that downward influence tactics have become a mediator for some variables to increase work outcomes (e.g., Chaturvedi et al., 2019; Lee \& Low, 2012). In this regard, it is possible that downward influence tactics have a role as a mechanism to understand the relationship between employee competency and employee's commitment. The more employees perceive themselves as competent, the more they perceive their supervisors use of consultation, ingratiation, and exchange tactics. Subordinates may perceive such tactics as the supervisors' concern and recognition of their competency, and, therefore, may increase their commitment. Thus, we propose that:

$\mathrm{H} 4 \mathrm{a}$ Consultation tactics mediates the relationship between employee competency and organizational commitment.

$\mathrm{H} 4 \mathrm{~b}$ Ingratiation tactics mediates the relationship between employee competency and organizational commitment.

H4c Exchange tactics mediates the relationship between employee competency and organizational commitment.

H5a Consultation tactics mediates the relationship between employee competency and commitment to the supervisor. 
$\mathrm{H} 5 \mathrm{~b}$ Ingratiation tactics mediates the relationship between employee competency and commitment to the supervisor.

H5c Exchange tactics mediates the relationship between employee competency and commitment to the supervisor.

Figure 1: Research Framework

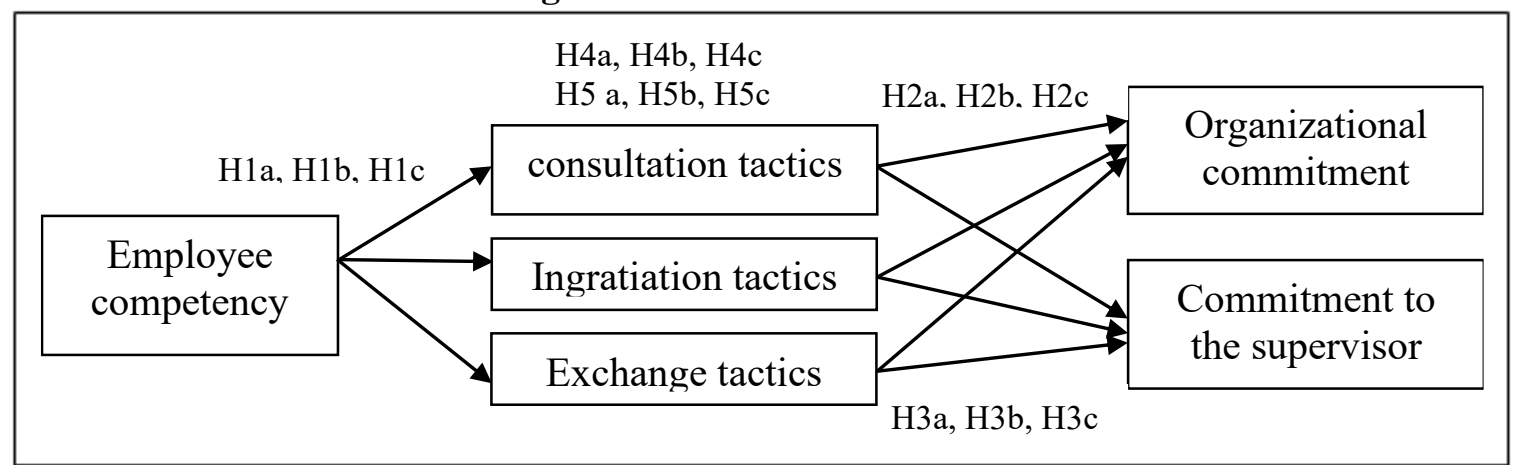

\section{Research Method}

\section{Respondent}

The study population is employees who work in various occupations and industries in Surabaya. The unit of analysis of this study is individuals. This study used a purposive sampling method (i.e., non-managerial employees and levels of education). Data collection was done by distributing questionnaires to 250 non-managerial employees who work in various industries (e.g., Finance, education, wholesale and retail trade, scientific and technical services) in Surabaya - Indonesia. Surabaya is the secondlargest city in Indonesia and is a business center for eastern Indonesia (Oxford Business Group, 2018). Thus, it is possible that there is a competition between organizations to hire employees with high competence. As many as 203 copies (response rate of $81 \%$ ) could be further analyzed. Based on calculations using GPower software, the minimum sample size for this study is 129 samples (Faul et al., 2007). As shown in Table 1, The respondents were mostly women (112 persons or $55 \%$ ), not married (111 persons or 55\%), aged less than 35 years (136 persons or $67 \%$ ), have tenure of less than five years (118 persons or $58 \%)$, educated with bachelor's degree (113 persons or $56 \%$ ), with the most of them work as clerical/office staff (49 persons or $24 \%$ ), teacher (47 persons or $23 \%$ ), and salesperson (44 persons or $22 \%$ ). 
Table 1: The Profile of Respondents

\begin{tabular}{llcc}
\hline $\begin{array}{l}\text { Demographic } \\
\text { variables }\end{array}$ & Category & Frequency & Percentage \\
\hline Gender & Male & 91 & 44.8 \\
& Female & 112 & 55.2 \\
Marital status & Single & 111 & 54.7 \\
& Married & 92 & 45.3 \\
Education & High school & 41 & 20.2 \\
& Associate Degree & 12 & 5.9 \\
& Undergraduate & 113 & 55.7 \\
& Graduate & 37 & 18.2 \\
Age (years) & $<25$ & 60 & 29.6 \\
& $25-<35$ & 76 & 37.4 \\
& $35-<45$ & 42 & 20.7 \\
Tenure (years) & $>=45$ & 25 & 12.3 \\
& $<1$ & 43 & 21.2 \\
& $1-<5$ & 75 & 36.9 \\
& $5-<10$ & 33 & 16.3 \\
& $10-<15$ & 16 & 7.9 \\
& $\geq 15$ & 36 & 17.7 \\
\hline
\end{tabular}

\section{Measures}

Employee competency is measured using a 5-item short version of Sense of Competence instrument that has been used by Sekaran and Wagner (1980) (e.g., mastering this job has meant a lot to me). Downward influence tactics are measured using a 3-item of exchange tactic (e.g., my supervisor offers to give me something I want in return for my help on a task or project), a 3-item of consultation tactic (e.g., my supervisor asks me to help plan an activity or project that he/she wants me to support or carry out), and a 4-item of ingratiation tactic (e.g., my supervisor compliments me about something before making a request) from the Influence Behavior Questionnaire-2000 (IBQ-2000) that has been used by Soetjipto (2002). Organizational commitment is measured using a 15-item from Mowday et al., (1979) (e.g., I talk up this organization to my friend as a great organization to work for). Commitment to the supervisor is measured using a 10-item (e.g., my supervisor means a lot to me) that has been used by Landry and Vandenberghe (2009) (e.g., my supervisor means a lot to me). Respondents were asked to rate on a 5 points Likerttype scale $(1=$ strongly disagree to $5=$ strongly agree). This study used PLS-SEM to test the measurement model (internal consistency reliability, convergent, and discriminant validity) and analyze the structural model for hypothesis testing.

\section{Results}

\section{Measurement Model}

Regarding the Common Method Variance issue, this study has used several methods to minimize the occurrence of bias as suggested by Podsakoff et al., (2003). Respondents to this survey completed the questionnaire anonymously and were asked to answer truthfully and were given clear questionnaire filling instructions. To 
guarantee the confidentiality of the data, respondents returned the completed questionnaire in sealed envelopes. The study also conducted Harman's Single Factor technique that showed no single factor and that the largest variance explained by the first factor was $29.04 \%$. This result showed that the common method variance is not significant.

Testing the measurement model included internal consistency reliability, convergent, and discriminant validity. Table 2 shows the results of internal consistency reliability and convergent validity. All loading factors showed values above 0.6 (this study did not maintain some items having a loading below 0.6), and Composite Reliability (CR) has shown values above the minimum requirement of 0.7 . The test result also shows a good convergent validity referring to the AVE value above 0.5 (Hair et al., 2017). Discriminant validity was tested using the Heterotrait-Monotrait (HTMT) ratio of correlations technique. Table 3 shows that all constructs have met the criteria of HTMT < 0.85, so that all constructs are conceptually different (Hair et al., 2017). Model fit is measured using the standardized root mean square residual (SRMR), which shows a value of 0.074 . The value is lower than 0.08 , so it is considered a good fit (Hu \& Bentler, 1999).

Table 2: Internal Consistency and Convergent Validity

\begin{tabular}{|c|c|c|c|c|c|}
\hline Construct & Indicator & Loading & $\begin{array}{l}\text { Composite } \\
\text { Reliability }\end{array}$ & $\begin{array}{l}\text { Cronbach's } \\
\text { Alpha }\end{array}$ & AVE \\
\hline $\begin{array}{l}\text { Competency } \\
\text { (COMP) }\end{array}$ & $\begin{array}{l}\text { COMP1 } \\
\text { COMP2 } \\
\text { COMP3 } \\
\text { COMP4 } \\
\text { COMP5 }\end{array}$ & $\begin{array}{l}0.818 \\
0.780 \\
0.786 \\
0.886 \\
0.868\end{array}$ & 0.916 & 0.888 & 0.687 \\
\hline $\begin{array}{l}\text { Consultation } \\
\text { (CONS) }\end{array}$ & $\begin{array}{l}\text { CONS1 } \\
\text { CONS2 } \\
\text { CONS3 }\end{array}$ & $\begin{array}{l}0.820 \\
0.860 \\
0.854\end{array}$ & 0.882 & 0.800 & 0.713 \\
\hline $\begin{array}{l}\text { Ingratiation } \\
\text { (ING) }\end{array}$ & $\begin{array}{l}\text { ING1 } \\
\text { ING2 } \\
\text { ING3 } \\
\text { ING4 }\end{array}$ & $\begin{array}{l}0.819 \\
0.891 \\
0.847 \\
0.637\end{array}$ & 0.879 & 0.828 & 0.647 \\
\hline $\begin{array}{l}\text { Exchange } \\
\text { (EXC) }\end{array}$ & $\begin{array}{l}\text { EXC1 } \\
\text { EXC2 } \\
\text { EXC3 }\end{array}$ & $\begin{array}{l}0.802 \\
0.895 \\
0.804\end{array}$ & 0.873 & 0.781 & 0.697 \\
\hline $\begin{array}{l}\text { Organizational } \\
\text { Commitment } \\
\text { (OC) }\end{array}$ & $\begin{array}{l}\text { OC1 } \\
\text { OC2 } \\
\text { OC3 } \\
\text { OC5 } \\
\text { OC6 } \\
\text { OC10 } \\
\text { OC13 } \\
\text { OC14 }\end{array}$ & $\begin{array}{l}0.697 \\
0.765 \\
0.757 \\
0.707 \\
0.762 \\
0.698 \\
0.723 \\
0.694\end{array}$ & 0.899 & 0.872 & 0.527 \\
\hline $\begin{array}{l}\text { Commitment to } \\
\text { the Supervisor } \\
\text { (SC) }\end{array}$ & $\begin{array}{l}\text { SC3 } \\
\text { SC4 } \\
\text { SC5 } \\
\text { SC7 } \\
\text { SC8 } \\
\text { SC9 } \\
\text { SC10 }\end{array}$ & $\begin{array}{l}0.760 \\
0.824 \\
0.770 \\
0.824 \\
0.700 \\
0.720 \\
0.658\end{array}$ & 0.901 & 0.872 & 0.567 \\
\hline
\end{tabular}


Table 3. Discriminant Validity

\begin{tabular}{lcccccc}
\hline & COMP & CONS & EXC & ING & OC & SC \\
\hline COMP & & & & & & \\
CONS & 0.388 & & & & & \\
EXC & 0.284 & 0.707 & & & & \\
ING & 0.232 & 0.741 & 0.632 & & & \\
OC & 0.736 & 0.461 & 0.334 & 0.286 & & \\
SC & 0.476 & 0.608 & 0.401 & 0.456 & 0.635 & \\
\hline
\end{tabular}

This study uses PLS-SEM to test the hypotheses. Beforehand, collinearity testing was conducted. The result shows that all constructs have a Variance Inflation Factor (VIF) value less than 5 (Hair et al., 2017); so, there is no collinearity problem.

The results of hypothesis testing using the bootstrapping procedure are shown in Table 4 . The results of the path analysis show that employee competency is positively and significantly related to influence tactics, namely with consultation $(\beta=0.356, t=$ 5.833), ingratiation $(\beta=0.237, t=3.006)$, and exchange tactics $(\beta=0.243, t=$ 3.520). Thus, hypotheses $1 \mathrm{a}, 1 \mathrm{~b}$, and $1 \mathrm{c}$ are supported. The study also shows that consultation tactic is significantly related to organizational commitment $(\beta=0.335, t$ $=3.596)$, but ingratiation and exchange tactic have no significant relationship with this commitment ( $\beta=0.015, t=0.154 ; \beta=0.088, t=1.017$; respectively). Thus, hypothesis $2 \mathrm{a}$ is supported, but these results are not support hypotheses $2 \mathrm{~b}$ and $2 \mathrm{c}$. Furthermore, the results show that consultation and ingratiation tactics have significant relationship with commitment to the supervisor $(\beta=0.396, t=4.426$; $\beta=$ $0.157, t=2.205$; respectively), but exchange tactic has no significant relationships with this commitment $(\beta=0.035, t=0.427)$, thus hypotheses $3 \mathrm{a}$ and $3 \mathrm{~b}$ are supported. Furthermore, the result shows that only consultation tactic has mediation effect on the relationship between employee competency and organizational commitment $(\beta=0.119, t=2.522)$ and commitment to the supervisor $(\beta=0.141, t=$ 3.253). However, ingratiation and exchange tactics have no mediation effect on the relationship between employee competency and organizational commitment $(\beta=$ $0.003, t=0.134 ; \beta=0.021, t=0.812$; respectively), and commitment to the supervisor $(\beta=0.037, t=1.474 ; \beta=0.009, t=0.373$; respectively). Therefore, $\mathrm{H} 4 \mathrm{a}$ and H5a are supported. 
Table 4: Hypothesized Structural Model

\begin{tabular}{|c|c|c|c|c|}
\hline Hypothesis & Relationship & $\begin{array}{c}\begin{array}{c}\text { Path } \\
\text { coefficient }\end{array} \\
\end{array}$ & $\mathbf{t}$ & $\begin{array}{c}\text { Hypothesis } \\
\text { support }\end{array}$ \\
\hline H1a & $\begin{array}{l}\text { Employee competency } \rightarrow \\
\text { consultation tactic }\end{array}$ & 0.356 & 5.833 & Supported \\
\hline $\mathrm{H} 1 \mathrm{~b}$ & $\begin{array}{l}\text { Employee competency } \rightarrow \\
\text { ingratiation tactic }\end{array}$ & 0.237 & 3.006 & Supported \\
\hline $\mathrm{H} 1 \mathrm{c}$ & $\begin{array}{l}\text { Employee competency } \rightarrow \\
\text { exchange tactic }\end{array}$ & 0.243 & 3.520 & Supported \\
\hline $\mathrm{H} 2 \mathrm{a}$ & $\begin{array}{l}\text { Consultation tactic } \rightarrow \\
\text { organizational commitment }\end{array}$ & 0.335 & 3.596 & Supported \\
\hline $\mathrm{H} 2 \mathrm{~b}$ & $\begin{array}{l}\text { Ingratiation tactic } \\
\rightarrow \text { organizational commitment }\end{array}$ & 0.015 & 0.154 & Unsupported \\
\hline $\mathrm{H} 2 \mathrm{c}$ & $\begin{array}{l}\text { Exchange tactic } \rightarrow \\
\text { organizational commitment }\end{array}$ & 0.088 & 1.017 & Unsupported \\
\hline $\mathrm{H} 3 \mathrm{a}$ & $\begin{array}{l}\text { Consultation tactic } \rightarrow \\
\text { commitment to the supervisor }\end{array}$ & 0.396 & 4.426 & Supported \\
\hline $\mathrm{H} 3 \mathrm{~b}$ & $\begin{array}{l}\text { Ingratiation tactic } \rightarrow \\
\text { commitment to the supervisor }\end{array}$ & 0.157 & 2.205 & Supported \\
\hline $\mathrm{H} 3 \mathrm{c}$ & $\begin{array}{l}\text { Exchange tactic } \rightarrow \text { commitment } \\
\text { to the supervisor }\end{array}$ & 0.035 & 0.427 & Unsupported \\
\hline $\mathrm{H} 4 \mathrm{a}$ & $\begin{array}{l}\text { Competency } \rightarrow \text { Consultation } \rightarrow \\
\text { organizational commitment }\end{array}$ & 0.119 & 2.522 & Supported \\
\hline $\mathrm{H} 4 \mathrm{~b}$ & $\begin{array}{l}\text { Competency } \rightarrow \text { Ingratiation } \rightarrow \\
\text { organizational commitment }\end{array}$ & 0.003 & 0.134 & Unsupported \\
\hline $\mathrm{H} 4 \mathrm{c}$ & $\begin{array}{l}\text { Competency } \rightarrow \text { Exchange } \rightarrow \\
\text { organizational commitment }\end{array}$ & 0.021 & 0.812 & Unsupported \\
\hline H5a & $\begin{array}{l}\text { Competency } \rightarrow \text { Consultation } \rightarrow \\
\text { commitment to the supervisor }\end{array}$ & 0.141 & 3.253 & Supported \\
\hline $\mathrm{H} 5 \mathrm{~b}$ & $\begin{array}{l}\text { Competency } \rightarrow \text { Ingratiation } \rightarrow \\
\text { commitment to the supervisor }\end{array}$ & 0.037 & 1.474 & Unsupported \\
\hline $\mathrm{H} 5 \mathrm{c}$ & $\begin{array}{l}\text { Competency } \rightarrow \text { Exchange } \rightarrow \\
\text { commitment to the supervisor }\end{array}$ & 0.009 & 0.373 & Unsupported \\
\hline
\end{tabular}

\section{Discussion}

The purpose of this study is to investigate the relationship between employee competency and downward influence tactics, downward influence tactics and employee's commitment to the organization and the supervisor, and the mediating effect of downward influence tactics. This study finds that employees' competency has a significant relationship with downward influence tactics (consultation, ingratiation, and exchange). Consistent with Lee and Low (2012), our finding indicates that competent employees experience more consulting tactics than the other two tactics. This study's context may explain this result. Respondents are members of Indonesian society with a high power distance culture. Wei et al. (2017) argued that individuals with high power distance prefer good and favorable supervisors compared to individuals with low power distance cultures. In a society with a higher power distance culture, power and decision-making powers are centralized, and power may mean privileges. As a result, subordinates may be less willing to express their opinions and suggestions to supervisors (Lin et al., 2019). This study indicates that supervisors have chosen a form of influence tactics that match a society's needs with a higher power distance tendency. Employees who are asked for advice and invited to 
discuss will feel that their supervisors appreciate their ability and have a close relationship with them. The consultation tactic shows supervisors' dependence on their subordinates and their willingness to share power with them (Lee \& Low, 2012). In addition, supervisors also tend to use the exchange tactic to influence their subordinates. This tactic will make subordinates obtain valuable resources from their superiors (Kim \& Gausdal, 2020). As a consequence, through these consultation and exchange tactics, subordinates may get some privileges because of their closeness to their supervisors.

This study finds that exchange tactics have no significant relationship with organizational commitment and commitment to the supervisor. In exchange tactics, rewards will be awarded if the target can complete the assigned task (Lee et al., 2017; Kim \& Gausdal, 2020). Thus, due to this gifting situation's conditional nature, subordinates may not want to respond to this tactic with a commitment to their supervisor and organization. In addition, exchange tactics not related to employee commitment are also possible because subordinates do not trust their supervisor's promises and are aware that the supervisor may not have the resources to provide rewards (Chong, 2014).

This study finds that ingratiation and consultation tactics are positively related to commitment to supervisors. Individuals targeted for consultation tactics will feel trusted, and ingratiation tactics will make the supervisors look friendly (Lee et al., 2017). Drawing from the social exchange theory, subordinates will feel obliged to reciprocate their supervisors' trust if they show high confidence in their intelligence, abilities, or other personal attributes (Organ, 1974). However, this study finds that ingratiation tactics have no significant relationship with organizational commitment. Individuals who experience ingratiation tactics from their supervisors will feel happy and supported (Chong, 2014) and have positive feelings (Falbe \& Yukl, 1992) and stronger relationship with them, and view them as attractive persons (Asawo \& George, 2018) so that subordinates want to fulfill their demands. Thus, it is possible that they only respond by committing to their supervisors because these tactics tend only to build interpersonal relationships between leader and follower. This study indicates that only consultation tactics can increase both commitments to the organization and the supervisors. This finding is consistent with Curtis (2018) that consultation tactics are effective in increasing employee commitment.

The result provides support for our suggestion that downward influence tactics have a mediating effect on the relationship between employee competency and employee commitments. But only consultation tactic has a mediation role on the relationship between employee competency and employee commitment. Individuals who are asked for ideas or suggestions may feel a sense of belonging to their organization because they participate in what might have taken place there (Falbe \& Yukl, 1992). Employees who experience consultation tactics have the opportunity to give their opinions, feel respected and trusted by their supervisors, and perceive positively to them (Liao \& Hui, 2019). Thus, it can be argued that individuals who perceive themselves as competent person and their supervisors asking for their suggestions will increase their commitment to the organization and their supervisors because they recognize their competence. 


\section{Managerial Implications}

This current study finds that employee competency has a positive relationship with downward influence tactics. Supervisors might use some form of influence tactics, such as consultation, ingratiation, and exchange tactics. This study showed that consultation tactics tend to increase the employees' commitment to supervisors and the organization. If a subordinate has multiple supervisors in the workplace, the supervisors' ability to engage in interesting downward tactics might allow the subordinates to care more about their preferred supervisor. This result shows why organizations need to provide understanding and training to individuals in managerial positions to have effective downward influence tactics.

Wei et al. (2017) suggest that organizations need to consider individuals who are pleasant and competent when choosing managers. Supervisors who are caring and known to be providing support will encourage their subordinates to commit to them (Emuwa, 2013; Chen et al., 2019). This study also indicates that organizations need to understand and train supervisors on various downward influence tactics, especially consultation tactics. This tactic can be used effectively to increase the willingness of their subordinates to fulfill the tasks assigned. In addition, since supervisors generally prefer subordinates who are perceived to have a certain competence to deliver job results, organizations need to pay attention and tighten the process of employee selection and training.

\section{Further Research Directions}

This study has a number of limitations related to the use of cross-sectional data. Future study may be able to capture these phenomena over different time spans. Although data in this study were obtained from self-report, the survey is based on anonymous data. This study investigates the effect of employee competency on downward influence tactics and the consequences of these tactics on employee's commitment to the organization and the supervisor. For future studies, it is suggested to investigate the role of individual employee attachment to supervisors, which may increase or decrease supervisors' willingness to use certain influence tactics, as well the relationship model of downward influence tactics - employee competency - employee commitment. Future studies may also consider the willingness of subordinates to perform tasks, in addition to competence, as offered in the theory of situational leadership by Hersey and Blanchard. Future studies need to identify the consequences of downward influence tactics, such as subordinate performance and the relationship quality between supervisors and subordinates.

\section{Implications for Asian Business}

This study indicates that the more competent employees perceive their supervisors using a downward influence tactic in the form of consultation, the more they will increase their commitment to supervisors and organizations. Referring to the study context, as in most countries in Asia, respondents are part of a society that tends to have a high power distance value (Zhang et al., 2019). People with a high power 
distance culture may have high organizational commitment if they experience strong ties with their supervisors as well as paternalistic treatment (Cohen, 2006). In the Asian community, employees tend to respect their supervisors and not take risks to do something outside their assigned duties (Larson \& Kleiner, 1992; Chen et al., 2019). Therefore, supervisors need to give credit for subordinates' work and encourage them to have initiative (Larson \& Kleiner, 1992). Based on this study's results, organizations need to manage their supervisors to use influence tactics that allow subordinates to feel trusted, cared for, and recognized for their abilities and regard them as family. This strategy can increase the ties between supervsiors and subordinates and subsequently increase employee commitment to supervisors.

Furthermore, related to subordinates' power, such as competence, may reduce their obedience and commitment to the organization (Tepper et al., 2009). Therefore, supervisors need to consider influence tactics that may increase employee commitment. Referring to the high power distance culture, employees tend to want their supervisors to act autocratically and show their power (Hofstede, 1983). In addition, in the principle of social exchange, individuals show their power as a valuable resource that can be exchanged to obtain benefits from other parties (Nunkoo, 2016). The selection of the right tactics is needed to show a reciprocal exchange over subordinates' power. In a particular context, such as in Indonesia, the values of superior-subordinate relations are strongly influenced by the Javanese culture as the largest ethnic group (Irawanto et al., 2012). Indonesian society tends to think of someone as their leader if they have several sources of power and are able to act as their father. As a father, this role can be demonstrated by the supervisor's ability to manage his/her subordinates' low profile, respect, trustworthiness, and responsibility (Irawanto et al., 2012). In regard to competent subordinates, supervisors need to show their power is not to be underestimated by their subordinates for leadership to be effective. Thus, in workplace exchange relationships, supervisors who have competent subordinates need to consider influence tactics that show their power to recognize, reward, be trusted to deliver on their promises, and willingness to listen to their subordinates' suggestions. Referring to our finding, to develop employee commitment, supervisors need to consider consulting tactics to influence their competent employees. In line with the Indonesian and Asian context, consultation tactics are likely to form employees' perception that they are recognized for their abilities. Consequently, they will be more confident in providing opinions and ideas related to work, they then will respond to the supervisors' kindness by giving their commitment.

Consistent with social exchange theory, supervisors' choice of appropriate influence tactics can be a pleasant reciprocate for competent employees. Both parties will experience mutually beneficial social exchange relationships. Competent subordinates may feel valued for their abilities, and supervisors may get help and support from them. In addition, supervisors can be considered by employees as representatives of the organization (Khattak et al., 2019). Therefore, selecting appropriate downward influence tactics may indirectly show that the organization also trusts and recognizes employee competencies. As a consequence, competent employees will give their commitments to the supervisor and the organization. 


\section{References}

Asawo, S.P. and George, B.M. (2018), "Leaders' intimidation impression management and subordinates' affective job commitment in Nigeria", International Journal of Organization Theory and Behavior, Vol. 21 No. 1, pp. 2-16.

Bunner, J., Prem, R. and Korunka, C. (2019), "How do safety engineers improve their job performance? The roles of influence tactics, expert power, and management support", Employee Relations, Vol. 42 No. 2, pp. 381-397.

Chae, S., Choi, T.. and Hur, D. (2017), "Buyer power and supplier relationship commitment: A cognitive evaluation theory perspective", Journal of Supply Chain Management, Vol. 53 No. 2, pp. 39-60.

Chaturvedi, S., Rizvi, I.A. and Pasipanodya, E.T. (2019), "How can leaders make their followers to commit to the organization? The importance of influence tactics", Global Business Review, Vol. 20 No. 6, pp. 1462-1474.

Chen, Y., Zhou, X. and Klyver, K. (2019), "Collective efficacy: Linking paternalistic leadership to organizational commitment", Journal of Business Ethics, Vol. 159 No. 2, pp. 587-603.

Chong, M.P.M. (2014), "Influence behaviors and organizational commitment: A comparative study", Leadership and Organization Development Journal, Vol. 35 No. 1, pp. 54-78.

Chong, M.P.M., Muethel, M., Richards, M., Fu, P.P., Peng, T.K., Shang, Y.F. and Caldas, M.P. (2013), "Influence behaviors and employees' reactions: An empirical test among six societies based on a transactional-relational contract model", Journal of World Business, Vol. 48 No. 3, pp. 373-384.

Cogliser, C.C., Schriesheim, C.A., Scandura, T.A. and Gardner, W.L. (2009), "Balance in leader and follower perceptions of leader-member exchange: Relationships with performance and work attitudes", Leadership Quarterly, Vol. 20 No. 3, pp. 452-465.

Cohen, A. (2006), "The relationship between multiple commitments and organizational citizenship behavior in Arab and Jewish culture", Journal of Vocational Behavior, Vol. 69 No. 1, pp. 105-118.

Cropanzano, R. and Mitchell, M.S. (2005), "Social exchange theory: An Interdisciplinary review", Journal of Management, Vol. 31 No. 6, pp. 874-900.

Curtis, G.J. (2018), "Connecting influence tactics with full-range leadership styles", Leadership and Organization Development Journal, Vol. 39 No. 1, pp. 2-13.

Deci, E.L. and Ryan, R.M. (2000), "Self-determination theory and the facilitation of intrinsic motivation, social development, and well-being", American Psychologist, Vol. 55 No. 1 , pp. 68-78.

Deniz, G., Percin, N.. and Cavusoglu, M. (2018), "The evaluation of influence tactics perception of hospitality establishment employees in terms of demographic variables", in Cobanoglu, G. and Corbaci, A. (Eds.), Advances in Global Business and Economics, Scholar Commons, Florida, p. 123.

Draganidis, F. and Mentzas, G. (2006), "Competency based management: A review of systems and approaches", Information Management \& Computer Security, Vol. 14 No. 1, pp. 51-64.

Emuwa, A. (2013), "Authentic leadership: Commitment to supervisor, follower empowerment , and procedural justice climate", Emerging Leadership Journeys, Vol. 6 No. 1 , pp. $45-65$.

Falbe, C.M. and Yukl, G. (1992), "Consequences for managers of using single influence tactics and combinations of tactics.", Academy of Management Journal, Vol. 35 No. 3, pp. 638-652.

Faul, F., Erdfelder, E., Lang, A.G. and Buchner, A. (2007), "G*Power 3: A flexible statistical power analysis program for the social, behavioral, and biomedical sciences", Behavior Research Methods, Vol. 39 No. 2, pp. 175-191.

Ferris, G.R., Liden, R.C., Munyon, T.P., Summers, J.K., Basik, K.J. and Buckley, M.R. (2009), "Relationships at work:Toward a multidimensional conceptualization of 
dyadic work relationships", Journal of Management, Vol. 35 No. 6, pp. 1379-1403.

Flint, D., Haley, L.M. and McNally, J.J. (2013), "Individual and organizational determinants of turnover intent", Personnel Review, Vol. 42 No. 5, pp. 552-572.

Fu, P.P. and Yukl, G. (2000), "Perceived effectiveness of influence tactics in the United States and China", Leadership Quarterly, Vol. 11 No. 2, pp. 251-266.

Group, O.B. (2018), "Surabaya's strategic location connects east and west | Indonesia 2018", Oxford Business Group, available at: https://oxfordbusinessgroup.com/analysis/soaring-surabaya-second-tier-citycapitalising-its-strategic-location-providing-connections-between (accessed 20 July 2020).

Hair, J.., Hult, G.T.M., Ringe, C.M. and Sarstedt, M. (2017), A Primer on Partial Least Squares Structural Equation Modeling (PLS-SEM), SAGE, second edi., California.

Han, Z., Wang, Q. and Yan, X. (2019), "How responsible leadership predicts organizational citizenship behavior for the environment in China", Leadership and Organization Development Journal, Vol. 40 No. 3, pp. 305-318.

Hansen, S.D., Alge, B.J., Brown, Michael E.Jackson, C.L. and Dunford, B.B. (2013), "Ethical leadership: Assessing the value of a multifoci social exchange perspective", Journal of Business Ethics, Vol. 115 No. 3, pp. 435-449.

Hofstede, G. (1983), "National Cultures in Four Dimensions : A research-based theory of cultural differences among nations", International Studies of Management \& Organization, Vol. 13 No. 1, pp. 46-74.

Hu, L.T. and Bentler, P.M. (1999), "Cutoff criteria for fit indexes in covariance structure analysis: Conventional criteria versus new alternatives", Structural Equation Modeling, Vol. 6 No. 1, pp. 1-55.

Hung, L.-M., Lee, Y.-S. and Lee, D.-C. (2018), "The moderating effect of salary satisfaction and working pressure on the organizational climate, organizational commitment to turnover intention", International Journal of Business and Society, Vol. 19 No. 1, pp. $103-116$.

Irawanto, D.W., Ramsey, P.L. and Tweed, D.C. (2012), "Exploring paternalistic leadership and its application to the Indonesian public sector", International Journal of Leadership in Public Services, Vol. 8 No. 1, pp. 4-20.

Khattak, M.N., Khan, M.B., Fatima, T. and Shah, S.Z.A. (2019), “The underlying mechanism between perceived organizational injustice and deviant workplace behaviors: Moderating role of personality traits", Asia Pacific Management Review, Vol. 24 No. 3, pp. 201-211.

Kim, T.E. and Gausdal, A.H. (2020), "Leaders' influence tactics for safety: An exploratory study in the maritime context", Safety, Vol. 6 No. 1, pp. 1-15.

Kipnis, D. and Schmidt, S. (1985), "The language of persuasion", Psychology Today, Vol. April, pp. 40-46.

Kipnis, D., Schmidt, S.M. and Wilkinson, I. (1980), "Intraorganizational influence tactics: Explorations in getting one's way", Journal of Applied Psychology, Vol. 65 No. 4, pp. 440-452.

Van Knippenberg, B., Van Knippenberg, D., Blaauw, E. and Vermunt, R. (1999), "Relational considerations in the use of influence tactics", Journal of Applied Social Psychology, Vol. 24 No. 4, pp. 806-819.

Lam, M., O’Donnell, M. and O'Donnell, M. (2015), “Achieving employee commitment for continuous improvement initiatives", International Journal of Operations and Production Management, Vol. 35 No. 2, pp. 201-215.

Landry, G. and Vandenberghe, C. (2009), "Role of commitment to the supervisor, leadermember exchange, and supervisor-based self-esteem in employee-supervisor conflicts", Journal of Social Psychology, Vol. 149 No. 1, pp. 5-27.

Larson, H.H. and Kleiner, B.H. (1992), "Understanding and effectively managing Asian employees", Equal Opportunities International, Vol. 11 No. 2, pp. 18-23.

Lee, K. and Salleh, A. (2009), "Examining the determinants and outcomes of superior downward influence tactics: the mediating impact of role ambiguity and subordinates' 
competence level", International Business Research, Vol. 1 No. 3, pp. 67-79.

Lee, K.L. and Low, G.T. (2012), "The mediating effect of downward influence tactics on the relationship between leadership style and organizational citizenship behavior", Journal of Applied Business and Economics, Vol. 13 No. 2, pp. 59-96.

Lee, S., Han, S., Cheong, M., Kim, S.L. and Yun, S. (2017), "How do I get my way? A metaanalytic review of research on influence tactics", Leadership Quarterly, Vol. 28 No. 1, pp. 210-228.

Lian, L.K. and Tui, L.G. (2012), "The mediating effect of downward influence tactics on the relationship between leadership style and organizational citizenship behavior", Jurnal Pengurusan, Vol. 36 No. 2, pp. 3-16.

Liao, E.Y. and Hui, C. (2019), "A resource-based perspective on leader-member exchange : An updated meta-analysis", Asia Pacific J Manage, No. June, pp. 1-55.

Lin, X., Chen, Z.X., Tse, H.H.M., Wei, W. and Ma, C. (2019), "Why and when employees like to speak up more under humble leaders? The roles of personal sense of power and power distance", Journal of Business Ethics, Vol. 158 No. 4, pp. 937-950.

Meyer, J.P., Morin, A.J.S. and Vandenberghe, C. (2015), "Dual commitment to organization and supervisor: A person-centered approach", Journal of Vocational Behavior, Vol. 88, pp. 56-72.

Meyer, P.M. and Herscovitch, L. (2001), "Commitment in the workplace toward a general model”, Human Resource Management Review, Vol. 11, pp. 299-326.

Miserandino, M. (1996), "Children who do well in school: Individual differences in perceived competence and autonomy in above-average children.", Journal of Educational Psychology, Vol. 88 No. 2, pp. 203-214.

Mowday, R.T., Steers, R.M. and Porter, L.W. (1979), "The measurement of organizational commitment", Journal of Vocational Behavior, Vol. 14 No. 2, pp. 224-247.

Mutonyi, B.R., Slåtten, T. and Lien, G. (2020), "Empowering leadership, work group cohesiveness, individual learning orientation and individual innovative behaviour in the public sector: empirical evidence from Norway", International Journal of Public Leadership, Vol. 16 No. 2, pp. 175-197.

Naim, M.F. and Lenka, U. (2017), "Linking knowledge sharing, competency development, and affective commitment: Evidence from Indian Gen Y employees", Journal of Knowledge Management, Vol. 21 No. 4, pp. 885-906.

Nunkoo, R. (2016), "Toward a More Comprehensive Use of Social Exchange Theory to Study Residents' Attitudes to Tourism", Procedia Economics and Finance, Vol. 39, pp. 588-596.

Organ, D.W. (1974), "Social exchange and psychological reactance in a simulated superiorsubordinate relationship", Organizational Behavior and Human Performance, Vol. 142, pp. 132-142.

Paltu, A. and Brouwers, M. (2020), "Toxic leadership: Effects on job satisfaction , commitment, turnover intention and organisational culture within the South African manufacturing industry", Journal of Human Resource Management, Vol. 18, pp. 112.

Podsakoff, P.M. (1982), “Determinants of a Supervisor's use of rewards and punishmens: A literature review and suggestions for further research", Organizational Behavior and Human Performance, Vol. 29 No. 1, pp. 58-83.

Podsakoff, P.M., MacKenzie, S.B., Lee, J.Y. and Podsakoff, N.P. (2003), "Common method biases in behavioral research: A critical review of the literature and recommended remedies", Journal of Applied Psychology, Vol. 88 No. 5, pp. 879-903.

Sekaran, U. and Wagner, F.R. (1980), "Sense of competence: A cross-cultural analysis for managerial application", Group \& Organization Management, Vol. 5 No. 3, pp. 340352.

Shin, L.R. and Hyun, S.S. (2019), "Impact of managerial influence tactics on job creativity and performance: A focus on Korean airline service employees", Sustainability, Vol. 11 No. 16, pp. 1-14.

Soetjipto, B.W. (2002), Downward Influence in Leader-Member Relationships, Cleveland 
State University.

Sungu, L.J., Weng, Q. and Xu, X. (2019), “Organizational commitment and job performance: Examining the moderating roles of occupational commitment and transformational leadership", International Journal of Selection and Assessment, Vol. 27 No. 3, pp. 280-290.

Tepper, B.J., Carr, J.C., Breaux, D.M., Geider, S., Hu, C. and Hua, W. (2009), “Abusive supervision, intentions to quit, and employees ' workplace deviance: A power/dependence analysis", Organizational Behavior and Human Decision Processes, Vol. 109 No. 2, pp. 156-167.

Tepper, B.J., Eisenbach, R.J., Kirby, S.L. and Potter, P.W. (1998), "Test of a justice-based model of subordinates' resistance to downward influence attempts", Group and Organization Management, Vol. 23 No. 2, pp. 144-160.

Vandenberghe, C., Bentein, K. and Stinglhamber, F. (2004), "Affective commitment to the organization, supervisor, and work group: Antecedents and outcomes", Journal of Vocational Behavior, Vol. 64 No. 1, pp. 47-71.

Wei, C., Sun, X., Liu, J., Zhou, C. and Xue, G. (2017), "High power distance enhances employees' preference for likable managers: A resource dependency perspective", Frontiers in Psychology, Vol. 7 No. Jan, pp. 1-14.

Yousaf, A., Yang, H. and Sanders, K. (2015), "Effects of intrinsic and extrinsic motivation on task and contextual performance of Pakistani professionals", Journal of Managerial Psychology, Vol. 30 No. 2, pp. 133-150.

Yukl, G. (2002), Leadership in Organizations, Prentice Hall. Inc., New Jersey.

Yukl, G. and Falbe, C.M. (1990), "Influence tactics and objectives in upward, downward, and lateral influence attempts", Journal of Applied Psychology, Vol. 75 No. 2, pp. 132140.

Yukl, G. and Michel, J.W. (2007), "Power and influence in organizations: New empirical and theoretical perspectives", Personnel Psychology, Vol. 60 No. 3, pp. 784-787.

Zhang, Y., Zheng, Y., Zhang, L., Xu, S., Liu, X. and Chen, W. (2019), "A meta-analytic review of the consequences of servant leadership: The moderating roles of cultural factors", Asia Pacific Journal of Management, pp. 1-30. 